\title{
Teleological vs. Scientific views of evolution theory among high school biology teachers in Argentina, Brazil, and
} Uruguay

\author{
Heslley Machado Silva a, 1, *, Gonzalo Peñaloza b, ${ }^{2}$, Robert A. Michaels c, 3 , Graça S. Carvalho d, 4 \\ ${ }^{a}$ University Center of Formiga, Formiga, Brazil \\ ${ }^{\text {b } C e n t r o ~ d e ~ I n v e s t i g a c i o ́ n ~ y ~ d e ~ E s t u d i o s ~ A v a n z a d o s ~ d e l ~ I P N, ~ U n i d a d ~ d e ~ M o n t e r r e y, ~ M o n t e r r e y, ~ M e x i c o ~}$ \\ c RAM TRAC Corporation, Schenectady, New York, United States \\ ${ }^{\mathrm{d}}$ Institute of Education, CIEC, University of Minho, Braga, Portugal \\ ${ }^{1}$ heslley@uniformg.edu.br *; ${ }^{2}$ g.pjimenez@cinvestav.mx; ${ }^{3}$ ram@ramtrac.com; ${ }^{4}$ graca@ie.uminho.pt \\ * Corresponding author
}

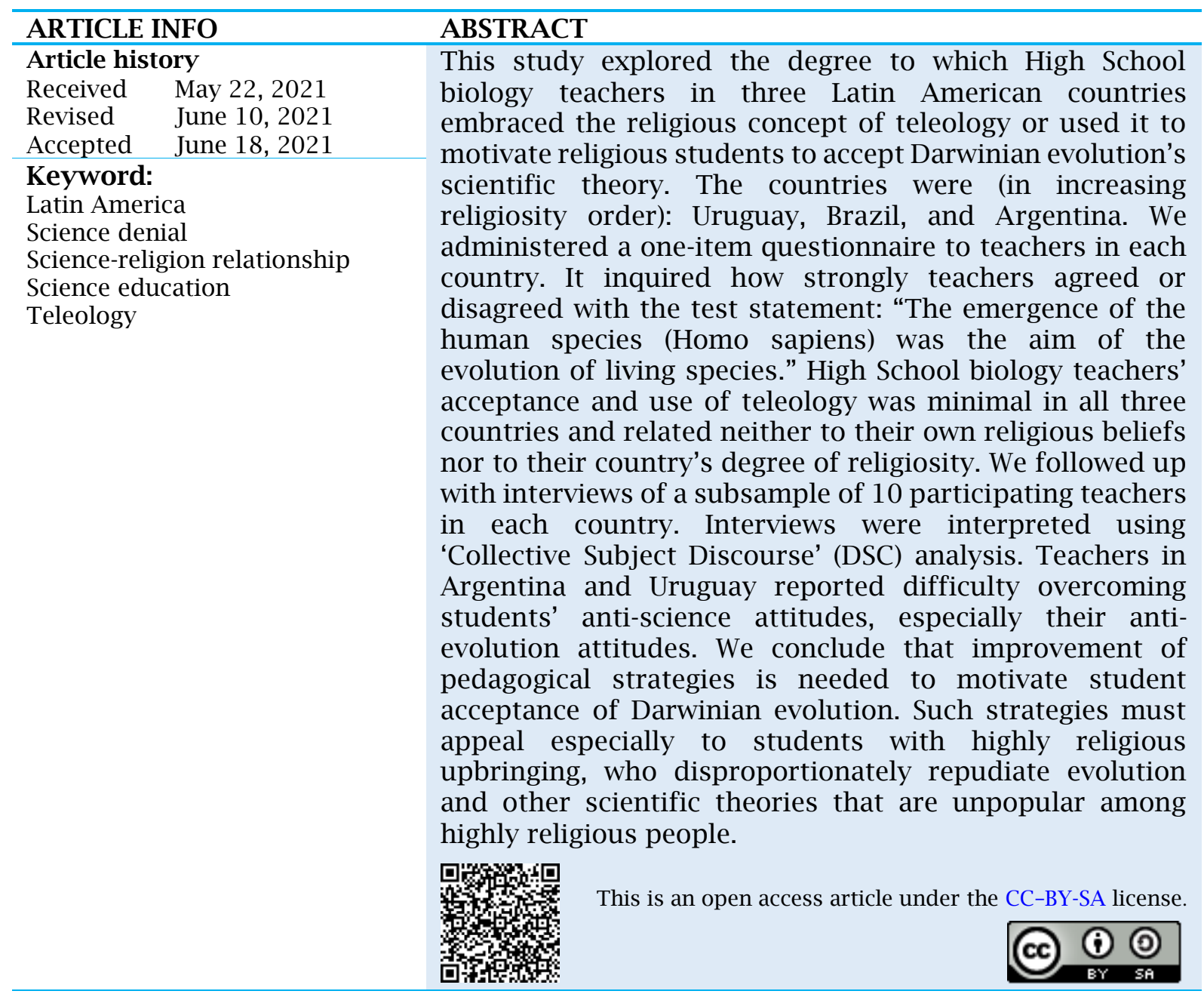

\section{Introduction}

Teaching evolution theory and other scientific curriculum content may be difficult if the scientific content conflicts with teachers' and students' religious beliefs. Such difficulties may be reduced if science is 'sugar-coated' with unscientific teleological ideas such as that a deity employed evolution for the religious purpose of fashioning humans in the image of their creator. The temptation to use this non-scientific concept would seem especially great in traditionally religious 
(non-secular) regions, which might have a preponderance of traditionally religious schools with students repudiating science that they perceive as threatening their religious upbringing and beliefs.

'Teleology' refers to the fact or quality of being directed towards a specific end, or having an ultimate purpose, especially attributed to natural phenomena (Paley, 2012). Particularly in biology, descriptions and explanations that ascribe goaldirectedness to natural phenomena are commonly interpreted as teleological. Indeed, some scholars have asserted that teleology is inherent in Darwinian thinking, especially concerning two premises: natural selection is a deterministic agent that guides evolution toward a betteradapted state and that evolution advances from organismal simplicity to complexity (Kampourakis, 2020; McGhee, 2016). Both premises sometimes may be correct, but both are false as generalities.

Naturally selected individuals preferentially survive and reproduce in their environment, but they are neither intrinsically nor permanently fittest in all environments. Indeed, organismal fitness tracks environmental conditions. As environments may fluctuate, fitness likewise may fluctuate, along with frequencies of naturally selected genotypes in populations. Evolution, therefore, is not intrinsically 'directional'.

Our basis for rejecting teleological explanation is more than semantic; it is historical. Teleology historically has been linked to religious views that seek to explain the world, most notably embodied in two fundamental ideas: perfection, and an assigned role for each organism, according to a theistic plan serving all life, by which the world works. These ideas are linked via the concept that a supernatural force created the world, imparted meaning, assigned functions to all things, and joined together in working harmoniously toward achieving a divine purpose (Ribeiro et al., 2015).

Notwithstanding the above generalities about evolution theory, science educators have used teleology as a linguistic resource and educational strategy (Galli \& Meinardi, 2011). For example, educators have sought to explain the convergent evolution of wings in insects, birds, and bats by using teleological arguments, asserting that such structures were developed for flight. Non- scientists (and sometimes scientists) may think of evolution teleologically, thereby promoting this non-scientific viewpoint, even if unintentionally. For example, they sometimes explain evolutionary phenomena ambiguously, unintentionally feeding teleology's perception in their messaging (Galli \& Meinardi, 2011; Kampourakis, 2020; Kampourakis et al., 2012). Teleological thinking seems to be almost instinctive for religious people to search for the sacred, for the meaning of life, or satisfy personal religious needs (Skrzypińska, 2014).

We investigate whether biology teachers in the three countries exhibit this unscientific bias regarding evolution and, especially, human origin and evolution. This work is part of a pilot study within broader research about the human mind's perceptions and humans' place in nature. The present study focuses on secondary school biology teachers in three Latin American countries. They are, in increasing order of religiosity (and decreasing order of secularism): Uruguay > Brazil > Argentina (Oro, 2008). Argentina is the most religious country, having incorporated Catholicism in its Constitution. Brazil is of intermediate religiosity. Uruguay is the least religious of the three countries (Oro, 2008). We investigated whether the beliefs of biology teachers in these countries are related to the degree of religiosity of their respective countries. More specifically, we explored whether biology teachers believed that a deity directed human evolution separately from the evolution of other organisms, as posited by religious doctrines such as the Christian Doctrine of Separate Creation.

In general, this study inquired whether and how participants' personal religious beliefs might relate to their scientific beliefs as professional biology teachers. This issue is especially interesting in the context of the growing diversity of religious beliefs represented in Latin America. Despite the predominance of Catholics in Latin America, other Christian religions also are represented significantly (Smith \& Prokopy, 1999). This religious spectrum imparts great importance to understanding the impacts of teachers' religious beliefs on Latin American cultures and potential challenges to teaching Darwinian evolution and related subjects, such as geology and cosmology. These academic subjects historically have 
conflicted with religious beliefs (Gumucio, 2005), most notably including creationism (Alves, 2015) and its euphemisms 'creation science' and 'intelligent design', which are growing markedly, particularly in Brazil (Silva, 2017; Silva et al., 2016).

\section{Method}

Three Latin American countries were selected differing in their degree of secularity (Uruguay more secular, Brazil supposedly with intermediate secularism and Argentina less laic) to explore how much teachers embraced teleology and/or used it to sell evolution theory to their students. A one-question questionnaire was administered to a sample of High School biology teachers. Our questionnaire asked teachers and non-teachers in the three countries to indicate the degree to which they agreed or disagreed with the test statement: "The emergence of the human species (Homo sapiens) was the aim of the evolution of living species." The questionnaire was followed by interviews with a subsample of responding teachers. Our null hypothesis was that the pattern of biology teacher acceptance of teleology resembled that of their home country.

Neither the number of teachers who were approached to answer the questionnaire nor the number who answered it constituted a fixed or predetermined fraction of regional populations in any of the three countries. Instead, questionnaires were applied in towns of comparable size, with metropolitan areas of comparable population. In each of the three countries, one town served as our research base: in Argentina, Belo Horizonte in Brazil, and in Uruguay, Montevideo. A sample of at least 50 biology teachers was adopted for each town. In fact, 50 questionnaires were returned in Buenos Aires, 62 in Belo Horizonte, and 57 in Montevideo. This small target number was consistent with the research budget and the status of a pilot study that might justify larger followup research, which may be deemed appropriate based on the findings.

The analytical tools included the "KVP model" (Carvalho \& Clément, 2007) and the four science/religion relationship categories of Barbour (1990). The KVP model considers scientific knowledge (K), moral and religious values (V), and social and professional practices (P). Statistical comparisons of questionnaire responses from each country were made via the STATISTICA 5.5 software, applying the Kruskal Wallis test to identify significant differences at the 95\% confidence level (alpha $\leq 0.05$ ).

To complement and deep the questionnaire analysis, 10 High School biology teachers in each country (total, 30 teachers) were interviewed. Teachers were selected for interviews based upon accessibility and experience in teaching evolution. Semi-structured interviews were conducted, inspired by Cobern (2000)' methodology, in which interviewees were allowed to discuss the interview topic freely. Interviews were analyzed with the methodology of Collective Subject Discourse (DSC) (Lefevre \& Lefevre, 2014). This method characterizes "Social Representation," which seeks to place interviewee perception in the context of a synthesized collective perception. For example, participants were asked if they believed teleology might constitute an obstacle to effective science teaching.

\section{Results and Discussion}

In Argentina, biology teacher respondents included 36 women and 14 men, ranging from 22 to 50 years old. Teachers responding in Brazil included 42 women and 20 men, ranging from 22 to 58 years. Uruguay teachers included 45 women and 12 men, ranging from 22 to 58 , as in Brazil. No specific relationship was detected between the gender and age of the teachers with their conceptions about evolution; however, these data were presented only to describe the profile of the investigated sample. All the individuals surveyed had completed a higher education degree in Biology, and all were employed as High School biology teachers during the research period.

Table 1 shows the distribution (by percentage) of participating teachers' declared religions and Table 2 in each country's general population (based upon Oro, 2008). Differences between the teacher samples vs general populations of each country are evident. For example, Argentinian teachers exhibited a higher proportion of Agnostic/Atheist belief (26\%) than Argentina's general population (2\%). Fifty-five per cent of participating biology teachers in Brazil were Catholic, compared with $74 \%$ in Brazil's general population. 
Table 1.Declared religions of Biology teachers in Argentina, Brazil, and Uruguay

\begin{tabular}{llllllll}
\hline Countries & $\begin{array}{c}\text { Catholics } \\
\text { (\%) }\end{array}$ & $\begin{array}{c}\text { Protestants } \\
\text { (\%) }\end{array}$ & $\begin{array}{c}\text { Spiritisms } \\
\text { (\%) }\end{array}$ & $\begin{array}{c}\text { Other } \\
\text { religion (\%) }\end{array}$ & $\begin{array}{c}\text { Did not } \\
\text { answer (\%) }\end{array}$ & $\begin{array}{c}\text { Agnostic/Atheist } \\
\text { (\%) }\end{array}$ \\
\hline Argentina & 58 & 4 & 0 & 6 & 6 & 26 \\
Brazil & 55 & 11 & 24 & 3 & 0 & 7 \\
Uruguay & 49 & 5 & 0 & 2 & 2 & 37 \\
\hline
\end{tabular}

Overall, High School biology teachers in each of the three countries disagreed with the test statement: "The emergence of the human species (Homo sapiens) was the aim of the evolution of living species." The answer proportions were similar among countries (Figure 1), and a Kruskal Wallis test confirmed the absence of statistically significant differences among the three countries $(\mathrm{H}=1.71, \mathrm{p}=0.43)$.

High School biology teachers' belief in directed evolution was unrelated to their religion in all three countries. Among the three countries, Uruguay's teachers exhibited the least frequent disagreement with the test statement, even though Uruguay is the least religious of the three countries (Table 1 and Table 2). Biology teachers in Argentina exhibited less agreement with the teleological test statement than those in Uruguay, even though Argentina is the most religious country. Biology teachers in Brazil occupied an intermediate position.

DSC analysis revealed that evolution's teleological view was an obstacle to effective teaching evolution by two Argentinian teachers and one Uruguayan teacher. None of the ten interviewed Brazilian teachers mentioned this issue, suggesting that most of the 30 total interviewed teachers did not consider their religiosity an obstacle to teaching evolution theory scientifically. However, some teachers alerted us to the related concern about student resistance to Darwinian evolution theory, especially among religious students, particularly when evolution was taught without teleological 'sugar-coating'.

Although teleology acceptance among teachers was relatively unimportant, the issue of student acceptance of teleology was not. Although reported by only one teacher from Uruguay, this teacher made clear that the teleological perception of evolution is common among students there. She also indicated students' perception that evolution is linearly directed toward individual (rather than species) adaptation and improvement:

"Another problem that I see is that students often perceive a purpose in evolution. They understand, despite my insistence to the contrary, that an individual evolves towards something. If I grab an animal and change its habitat conditions, students will hypothesis that the animal will change to adapt to the changed habitat. And I cannot make the student come out of that belief."

A similar unscientific student view was described as follows by another Argentine teacher: "Even if I put some posters in the class that evolution does not aim for a final result, students believe that individuals will work to achieve a final adapted condition." This shows that biology teachers may realize the potential for theological thinking by their students to impede evolution learning, and suggests that they may lack pedagogical strategies to address this problem toward improving students' understanding of evolution.

No statistically significant differences were found among biology teachers in the three studied countries (Figure 1). Teachers' beliefs in teleology (or 'directed evolution') was unrelated to their declared religion. Indeed, no statistically significant difference was observed in the test question rejection rate between religious vs non-religious (agnostic and atheist) High School biology teachers in the three studied countries. Participating teachers of high religiosity, notwithstanding their religious beliefs, generally adhered to science over religion. Accordingly, our null hypothesis, that the pattern of biology teacher acceptance of teleology resembled that of their home country was rejected.

Table 2. Declared religions of the general population in Argentina, Brazil and Uruguay (source: Oro,

\begin{tabular}{lcccc}
\multicolumn{1}{c}{ Countries } & Catholics (\%) & Evangelicals (\%) & Others (\%) & Non-Religious (\%) \\
\hline Argentina & 88 & 8 & 2 & 2 \\
Brazil & 74 & 15 & 4 & 7 \\
Uruguay & 52 & 2 & 11 & 35 \\
\hline
\end{tabular}




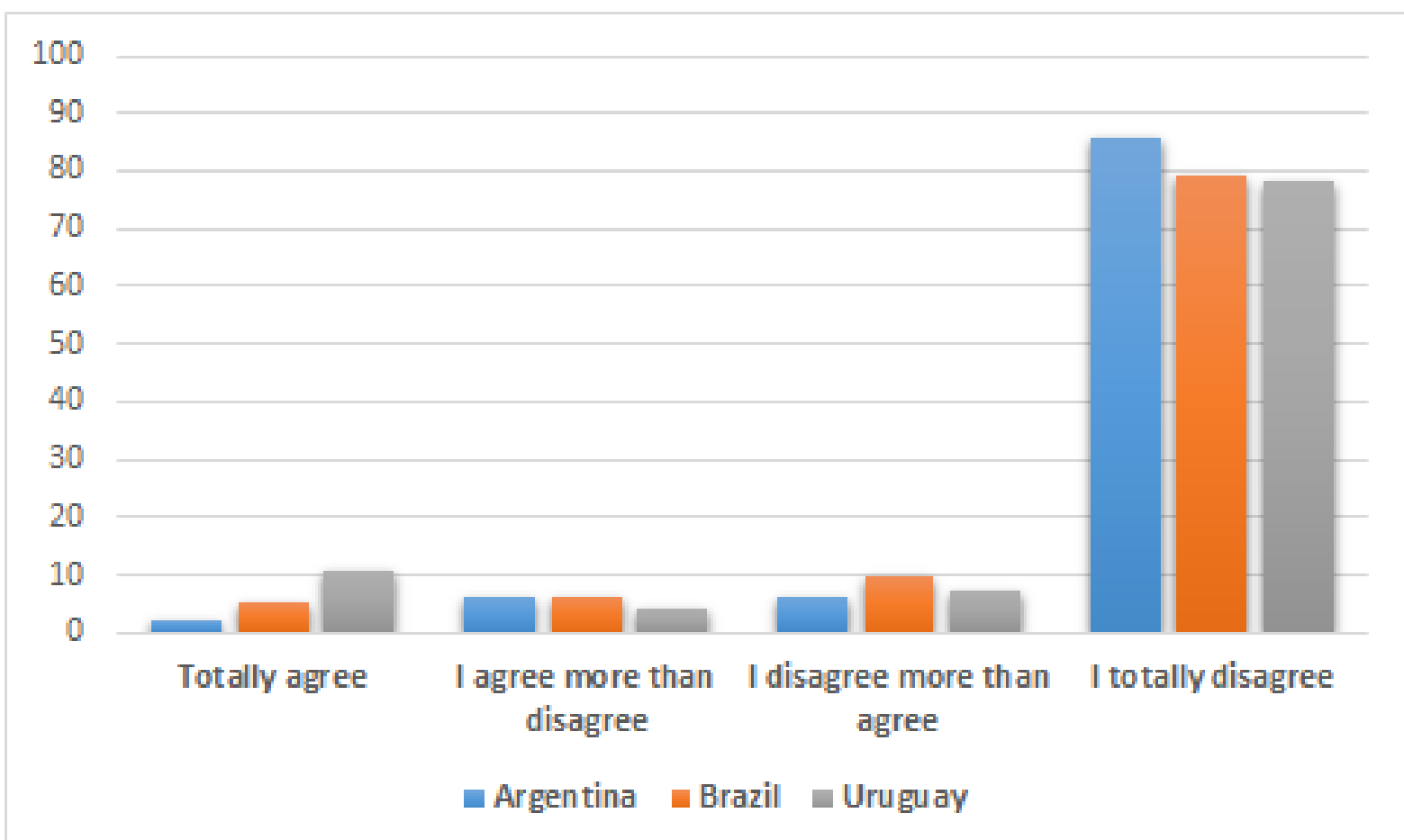

Figure 1. Strength of biology teacher agreement with test statement (The emergence of the human species (Homo sapiens) was the aim of the evolution of living species)

One of the most straight forward and most useful systems for characterizing the relationship between religious and scientific beliefs was proposed by Barbour (1990). Barbour classified this relationship into just four typologies: conflict, independence, dialogue, and integration, each briefly defined as follows:

Conflict: Science and religion are viewed as conflicting with one another. Independence: Science and religion are viewed as separate belief systems that can be adopted independently and simultaneously, as they do not conflict with one another. Dialogue: Science and religion are viewed as parties in a conversation in which each belief system informs the other about its area of knowledge. Integration: Science and religion are viewed as cooperative in the endeavor to create a world view consisting of both belief systems, without which the worldview would be incomplete.

In general, models relating to science and religion modify the four Barbour typologies above. Artigas (2007), for example, reduces the four Barbour typologies to just three: hostility, indifference, and cooperation, while he also distinguishes between "weak" cooperation (Barbour's 'dialogue') vs "strong" cooperation (termed 'integration'). In contrast, Kung (2007) added a category of complementarity between dialogue and integration. Considering these options, Barbour's model was selected as a practical and commonly used tool to characterize the relationship between science and religion.

The null hypothesis if the pattern of biology teacher acceptance of teleology resembled that of their home country was rejected (Figure 1). Thus, these findings agree with other studies, in which religious affiliation constituted a reliable predictor neither of acceptance nor rejection of directed evolution. Likewise, our findings agree with other findings that religion does not constitute a reliable predictor of whether biology teachers would teach evolution (Levesque \& Guillaume, 2010; Losh \& Nzekwe, 2011). In short, teachers' belief in directed evolution has been found clearly to be unrelated to teachers' religion. Notably, the absence of a relationship between teacher religiosity and rejection of teleology included teachers with evangelical backgrounds, which have been strongly associated with evolution rejection, particularly with the rejection of human evolution (El-Hani \& Sepulveda, 2010).

In fact, Barbour's 'independence' category suggests a strong separation between science and religion. Distinct traditions mark science and religion, and 
their methods, topics, and languages differ. In short, science and religion do not compete (Coutinho \& Silva, 2013), and they should not interfere with one another (Michaels et al., 2018). Accordingly, most teachers did not accept religion as a scientific instrument for knowing the natural world or its material aspect. Instead, they approached religion from the perspective of aesthetics, mysticism, spirituality, or ethics (Reiss, 2009).

This position likewise was explained by the American evolutionary biologist Stephen Jay Gould (1941-2002), who proposed the principle of Non-Overlapping Magisteria ('NOMA'), in which science and religion constitute separate realms (Gould, 1997, 1999). Indeed, all religions hold fundamental assumptions about the existence of a supernatural or immaterial sphere of the world (Taber, 2013), but some do not reject the natural or material part explained by 'methodological naturalism' (Artigas, 2007). The NOMA conception of the science-religion relationship is broadly useful as a worldview compatible with science (Cobern, 1996). It enables religious people to maintain a narrow view of science, specifically as a pathway to practical knowledge of the natural world. It simultaneously enables them, therefore, to maintain belief in their pre-existing epistemological presuppositions.

Our study did not compare teacher vs student acceptance of evolutionary purpose quantitatively. Even so, a mismatch from interviews with teachers in the three countries was discerned. Only teachers from Argentina and Uruguay identified student teleological thinking, and student belief in directed evolution, as obstacles to their teaching of evolution. In contrast, other studies reported a relatively low incidence of students rejecting evolution in Brazil, although Brazilian students exhibited difficulties accepting human origin via Darwinian evolution (Oliveira \& Bizzo, 2011).

A teleological explanation is often helpful in demonstrating the role of natural selection, such as in explaining that birds developed flight because they had a survival instinct. This may imply that the adaptation in question (such as flight) constitutes a goal of evolution (F. Ayala, 1999). This teleological perspective was not found among the teachers interviewed. When present in students, however, it has proved to be a hindrance for teachers. Students may perceive evolution as linear and theistically directed, for example, starting from a simian hominid walking and gradually changing until it reaches a modern individual. Teachers have reported that weaning students from this incorrect view can be challenging, in part because it is embedded in common phraseology. This has been reported (Oleques et al., 2011), even among $80 \%$ of Brazilian teacher respondents, exhibiting a teleological bias.

Natural selection is a fundamental process for understanding Darwinian biological evolution, so teachers and students must have clearness on this topic. However, student understanding of evolution, even after years of instruction, commonly includes misconceptions persisting to post-school adulthood (Bishop \& Anderson, 1990; Nehm \& Reilly, 2007). At the heart of these misconceptions is the teleological perception that the current traits of organisms resulted from a history of implementing a divine blueprint (Pedersen \& Halldén, 1994; Ruse, 2000; Tamir \& Zohar, 1991).

Ultimately, the widespread perception that Darwinian thinking is intrinsically teleological is incorrect, but potential misuses of teleology in evolutionary reasoning are numerous (Woodford, 2016). Using teleology, even metaphorically, reinforces misconceptions, and therefore is harmful to teaching and learning about evolution. It is generally harmful in education, where it confuses students fundamentally (Ghiselin, 1994). Therefore, teachers must reject purpose as a scientific concept; such rejection reasonably would be expected to produce very significant educational value.

Human behavior is often purposeful, but human purposes must be distinguished from teleology, positing divine purpose. Making this distinction is a critical role of the teacher, who also should acknowledge the human purpose. Teachers thus must learn how to place evolution, and science in general, in the proper context of the scientific method. This means guiding students toward scientifically supportable explanations and away from unscientific alternative explanations. Most essentially, teachers have no basis to challenge religious belief, only to place religious belief outside of the 
realm of scientific belief. These examples illustrate the teachers' value of becoming sufficiently familiar with teleology arguments to tackle them flexibly when they arise in the classroom. Most essentially, teachers should learn to substitute a scientific explanation for each teleological explanation proposed by students.

The evident mismatch between teacher and student beliefs revealed in our research represents an important focus for further study. Making students understand evolution scientifically as a natural phenomenon has been achieved with only modest effort (Tamir, 1985), notwithstanding the attractiveness of teleological explanation, especially explaining human origins. Even so, teachers must improve their pedagogical skills and develop their methodological strategies for teaching Darwinian evolution (Galli \& Meinardi, 2011). Darwin himself recognized the difficulty of escaping teleology and its supernatural bias, which creationists proffer even today as proof (albeit spurious) of his theory's flaw. Even though Darwin showed that natural selection best explains organismal complexity and human origins, educators must carry the torch to assure continued acceptance, and broadened acceptance, of scientific over teleological explanation (Andrade, 2009).

\section{Teleology in science education}

Teleology has been employed strategically by believers in the Christian Doctrine of Separate Creation ('creationism') and its euphemistic spinoffs 'creation science' and 'intelligent design' (Silva, 2017). In contrast, science educators have used teleology as a linguistic resource and educational strategy (Galli \& Meinardi, 2011). For example, educators have sought to explain the convergent evolution of wings in insects, birds, and bats by using teleological arguments by asserting that such structures all were developed for the purpose of flying. The convergence of structures enabling flight among multiple animal phyla constitutes, for these educators, evidence that flight is an intrinsic goal of evolution (F. Ayala, 1999). However, such convergence can also be explained scientifically as arising from the flight (and its intermediate conditions, such as lofting and gliding), imparting an adaptive advantage to organisms in multiple phyla. As Kampourakis (2020) has pointed out, the problem is not using "functional explanations"; instead, it is the core issue in how teachers or students explain how those functions evolved.

Most educators and almost all evolutionary scientists agree that teleological content explanations are inadequate (Stover \& Mabry, 2007). Being inadequate, they should be excluded from science and biology curricula, for several reasons: (i) schools must serve as a counterpoint to the pervasive teleological and anthropomorphic view of evolution adopted by popular media such as movies and books; (ii) as a scientific argument teleology is not supported by probative evidence demonstrating divine design or purpose; (iii) teleological or anthropomorphic explanations have been ineffective for teaching evolution; (iv) teleological arguments in biological science textbooks have failed to improve students' understanding of evolution, as students seem to decide whether to adopt or not a teleological viewpoint (Zohar \& Ginossar, 1998).

Non-scientists (and sometimes scientists) may think of evolution teleologically), thereby promoting this nonscientific viewpoint, even if unintentionally. For example, they sometimes explain evolutionary phenomena ambiguously, unintentionally feeding teleology's perception in their messaging (Galli \& Meinardi, 2011; Kampourakis, 2020; Kampourakis et al., 2012). Teleological thinking seems to be almost instinctive for religious people to search for the sacred, life meaning, or satisfying personal demands in the religious field (Skrzypińska, 2014).

The above considerations provide a context for the widely accepted necessity of educators' finding ways to address teleological views of evolution among teachers and students in classrooms (González Galli et al., 2020; Kampourakis et al., 2012; Pérez et al., 2021). Such analysis should be undertaken via broad discussion involving, most notably, philosophy and history of biology, science education, educational psychology, and cultural perspectives. A framework of this breadth is important to allow teachers to reflect on the nature of scientific explanation, particularly biological explanation (Jungwirth, 1975). 
Using teleological explanations in teaching evolution may be controversial, but it may hamper science and science teaching as it is not scientific. The teleological view, especially if adopted by biology teachers, is vulnerable to use (or misuse) by religious movements to support creationism and intelligent design. Although teleology is not necessarily religious, it can be misused to advocate religious evolution teaching. This antiscientific viewpoint has been powerfully influential in Latin America, especially in Brazil.

Other factors besides religion (and the type of religion) also may be associated with teachers adopting or rejecting teleology. Such factors include gender, education, knowledge of genetics, attitude to life, belief in science and technology, and political ideology (Allmon, 2011; Brem \& Sinatra, 2012). These factors influence teachers' and students' conceptions of evolution (Deniz et al., 2008; Miller, 2006), but we focus more on the religious issue in this study.

\section{Teleology and creationism in Latin America}

Latin America is important as a focus for research on the teaching of evolution, especially due to changes that are underway in patterns of religious belief and secularity in this sub-continent. These changes may have relevant implications regarding Biology curricula, which historically have been a major focus of creationist action (Cornish-Bowden \& Cárdenas, 2007). Research on this topic is sparse, particularly in Brazil (Teixeira \& Neto, 2012), where a changing religious spectrum is beginning to affect education in public and private schools (Silva, 2015, 2017). Such research should address teachers' perceptions and conceptions about evolution and the development of teachers' thinking and possible regional differences (Oleques et al., 2011). Inevitably, the quality of teaching ultimately will be affected by the impact of each teacher's religious, philosophical, and cultural matrix. Therefore, research should focus on the possible evolution of biology teachers' attitudes about teleology and human origins.

Most essentially, creationism and its euphemisms 'creation science' and 'intelligent design' are religious, not scientific, concepts, as they are not subject to confirmation or refutation via the scientific method. Being non-scientific, they are inappropriate subjects for teaching as science, particularly for teaching in science classrooms either alongside Darwinian evolution or as an alternative to it (Scott \& Matzke, 2007). This point is worth illustrating.

Some creationists have endorsed evolution with the caveat that a deity guides it towards its apex: humans created in the image of God. One can test evolution scientifically, thereby refining it to improve its accuracy, but one cannot test whether a deity guides the process. Every scientific test that supports evolution also may be claimed to support creationism. However, no scientific test can refute creationism: any adverse result could be explained ad hoc as an expression of the divine will.

Furthermore, a biology teacher who accepts intelligent design may also incorporate teleology. In that case, teleology may serve those who seek to reconcile their introduction to science with their pre-existing religious upbringing and belief (Barbour, 1990). Nevertheless, the distinction between the belief systems of science and religion must be made. However, Shanks (2004) noted that some academic researchers still view intelligent design inappropriately as a scientific theory co-equal with, and alternative to, Darwinian evolution.

Intelligent design implies an intelligent designer (Kojonen, 2013). As such, it could qualify as a political and/or ideological movement, but it does not qualify as a scientific hypothesis or theory (Mayr, 1974). Furthermore, it does not qualify as a subject to be taught in school science classrooms (Pennock, 2001; Silva, 2017). As a matter of scientific fact: neither creationism, nor creation 'science', nor intelligent design qualifies as a scientific theory that is co-equal with Darwinian evolution; indeed, they are not scientific theories at all, and they are not science at all.

Controversy about the position of humans in nature pre-dates Charles Darwin. Darwin's disciple and defender, Huxley (1901), stated: "Among the many problems which came under my consideration, the position of the human species in zoological classification was one of the most serious". Nevertheless, rejection of human evolution has been recorded in Latin America since Darwin 
proposed it in Europe (Glick, 2010; Medel \& Veloso, 2009; Reda, 2016; R Ruiz, 1987; Rosaura Ruiz, 1987; Silva et al., 2021). This rejection has impaired the teaching of evolution, and especially of human evolution. Such rejection may be related to a religious worldview prevalent in Latin America, crediting God with the origin of the universe, life, and, eventually, human life (Oser et al., 2003).

A major misconception of the creationist movement is that science cannot explain complex organisms without invoking an intelligent designer (F. J. Ayala, 2007). To creationists, a chief failing of science is its failure to find fossil evidence of intermediate steps leading to complex structures, such as the human eye (Pigliucci, 2009, n. see above). This view persists despite numerous paleontological discoveries filling in the fossil record gaps in astonishing detail (Leakey, 1997; Lovejoy, 1981).

A second misconception relates to evolution rather than creationism. Specifically, creationists often subscribe to the Lamarckian belief in the heritability of acquired characteristics (Burkhardt, 2013; Handel \& Ramagopalan, 2010; Lamarck, 1914). Acceptance of this Lamarckian misconception among biology teachers has been reported to be an obstacle to effective teaching of Darwinian evolution (Jensen \& Finley, 1995; Silva, 2015).

No credible scientific evidence has cast doubt about humans' evolutionary origin or the underlying mechanism of natural selection favoring the fittest individuals, resulting in "descent with modification" (Francisco J. Ayala, 2007). Prüfer et al. (2012) showed evidence that the human species are genetically related to two African apes (chimpanzees and bonobos). Chimpanzees and humans share more than 95\% of their DNA (Britten, 2002), notwithstanding the apparent differences in their appearance (phenotypes). Indeed, the two ape species have been reported to share more than $99 \%$ of their respective functional genomes (Cheng, 2005).

Beyond their genetic resemblance, the anatomical similarities between humans, chimpanzees, and bonobos imply evolutionary kinship (Deloison, 1997). The evidence of kinship also has been reported to include cultural similarities (Boesch \& Tomasello, 1998), although cultural similarities alone do not demonstrate a relationship by descent. Even so, our
Neanderthal ancestors did exhibit cultural similarities that would seem to have a basis in evolutionary kinships, such as tool making and burying their dead. Evidence of mating between Neanderthals and modern humans also has been evinced (LaluezaFox, 2013).

\section{Conclusion}

Our findings justify further research into student/teacher interactions to understand their respective worldviews regarding scientific vs teleological explanation. Such investigations also, and ideally, should be aimed at harmonizing these respective worldviews. They are especially urgent in regions that are strongly influenced by religion, such as Latin American countries. This study is limited to the research on teachers' viewpoint, not the students' views collected directly. Therefore, a subsequent study might focus directly on students' thinking about evolution and teleology. Further research is needed to uncover the reasons for teachers in the three countries to reject teleology, and for others to accept it. A similar study must be carried out with students to know what factors distinguish between student acceptance vs rejection of teleology and what influences can be exerted by the internet or other media, especially science media.

The following future activities are recommended: (i) more research to elucidate reasons for accepting or rejecting evolution, especially in school settings; (ii) inquiring within various classroom environments to elucidate students' preconceptions; (iii) elucidation of multiple pedagogical strategies, and integration with other biology topics, to explain evolution; and (iv) study how field trips to museums, parks, aquariums, and outdoor classes, might help demonstrate examples of past and continuing evolution..

\section{Acknowledgment}

This article incorporates results from the research project titled "Science, Philosophy, and Theology: Capability Building in Latin America" funded by The John Templeton Foundation" under a research award held by the University of Oxford." It also had the financial support of the Portuguese national funds through the FCT (Foundation for Science and 
Technology) within the framework of the CIEC (Research Centre for Child Studies) of the University of Minho project under the reference UIDB/00317/2020.

\section{References}

Allmon, W. D. (2011). Why don't people think evolution is true? Implications for teaching, in and out of the classroom. Evolution: Education and Outreach, 4(4), 648665. https://doi.org/10.1007/s120 52-011-0371-0

Alves, E. F. (2015). Teoria do design inteligente. Clinical \& Biomedical Research, 35(4), 250-251. https://doi.org/10.4322/23579730.59738

Andrade, G. (2009). Evaluación de los principales argumentos creacionistas en contra de la teoría de la evolución. Interciencia, 34(5), 366-372.

https://www.interciencia.net/wpcontent/uploads/2018/01/366-eANDRADE-7.pdf

Artigas, M. (2007). Ciencia y religión:Conceptos fundamentales. EUNSA.

Ayala, F. (1999). Adaptation and novelty: Teleological explanations in evolutionary biology. History and Philosophy of the Life Sciences, 21(1), 3-33. http://www.jstor.org/ stable/23332201

Ayala, F. J. (2007). Darwin's greatest discovery: Design without designer. Proceedings of the National Academy of Sciences, 104(Supplement 1), 8567-8573. https://doi.org/10.1073/pnas.070 1072104

Ayala, Francisco J. (2007). Darwin y el diseño inteligente. Alianza.

Barbour, I. (1990). Religion in an age of science. Harper One.

Bishop, B. A., \& Anderson, C. W. (1990). Student conceptions of natural selection and its role in evolution. Journal of Research in Science Teaching, 27(5), 415-427. https://doi.org/10.1002/tea.36602 70503

Boesch, C., \& Tomasello, M. (1998). Chimpanzee and human cultures. Current Anthropology, 39(5), 591-
614. https://doi.org/10.1086/204 785

Brem, S. K., \& Sinatra, G. M. (2012). Evolution challenges: Integrating research and practice in teaching and learning about evolution (K. S. Rosengren, S. K. Brem, E. M. Evans, \& G. M. Sinatra (eds.)). Oxford University Press.

Britten, R. J. (2002). Divergence between samples of chimpanzee and human DNA sequences is $5 \%$, counting indels. Proceedings of the National Academy of Sciences, 99(21), 13633-13635. https://doi.org/10. 1073/pnas.172510699

Burkhardt, R. W. (2013). Lamarck, evolution, and the inheritance of acquired characters. Genetics, 194(4), 793-805. https://doi.org/ 10.1534/genetics.113.151852

Carvalho, G. S., \& Clément, P. (2007). Projecto "Educação em biologia, educação para a saúde e educação ambiental para uma melhor cidadania": Análise de manuais escolares e concepções de professores de 19 países (europeus, africanos e do próximo oriente). Revista Brasileira de Pesquisa Em Educação Em Ciências, 7(2).

Cobern, W. W. (1996). Worldview theory and conceptual change in science education. Science Education, 80(5), 579-610. https://doi.org/10.1002/ (SICI)1098-237X(199609)80:5<579:: AID-SCE5>3.0.CO;2-8

Cobern, W. W. (2000). Everyday thoughts about nature: A worldview investigation of important concepts students use to make sense of nature with specific attention to science. Kluwer Academic Publishers.

Cornish-Bowden, A., \& Cárdenas, M. L. (2007). The threat from creationism to the rational teaching of biology. Biological Research, 40(2), 113-122. https://doi.org/10.4067/S071697602007000200002

Coutinho, F. A., \& Silva, F. A. R. e. (2013). Ciência e religião: uma guerra desnecessária. Ciência Hoje, 18-21. https://cienciahoje.org.br/artigo/u ma-guerra-desnecessaria/

Deloison, Y. (1997). Description d'un astragale fossile de primate et 
comparaison avec des astragales de chimpanzés, d'Homo sapiens et d'hominidés fossiles: Australopithèques et Homo habilis. Comptes Rendus de l'Académie Des Sciences. Série 2, Earth \& Planetary Sciences, 324(8), 685-692.

Deniz, H., Donnelly, L. A., \& Yilmaz, I. (2008). Exploring the factors related to acceptance of evolutionary theory among Turkish preservice biology teachers: Toward a more informative conceptual ecology for biological evolution. Journal of Research in Science Teaching, 45(4), 420-443. https://doi.org/10.1002/tea.20223

El-Hani, C. N., \& Sepulveda, C. (2010). The relationship between science and religion in the education of protestant biology preservice teachers in a Brazilian university. Cultural Studies of Science Education, 5(1), 103-125. https://doi.org/10.1007/s11422009-9212-7

Galli, L. M. G., \& Meinardi, E. N. (2011). The role of teleological thinking in learning the darwinian model of evolution. Evolution: Education and Outreach, 4(1), 145-152. https://doi.org/10.1007/s12052010-0272-7

Ghiselin, M. T. (1994). Darwin's language may seem teleological, but his thinking is another matter. Biology \& Philosophy, 9(4), 489-492. https://doi.org/10.1007/BF008503 77

Glick, T. F. (2010). The comparative reception of Darwinism: A brief history. Science \& Education, 19(68), 693-703. https://doi.org/10. 1007/s11191-010-9235-1

González Galli, L., Peréz, G., \& Gómez Galindo, A. A. (2020). The selfregulation of teleological thinking in natural selection learning. Evolution: Education and Outreach, 13(1), Article 6. https://doi.org/10. 1186/s12052-020-00120-0

Gould, S. J. (1997). Nonoverlapping magisteria. Natural History, 106(2), 16-22.

Gould, S. J. (1999). Rocks of ages: Science and religion in the fullness of life. Random House Publishing Group.
Gumucio, C. P. (2005). ¿América Latina ya no es católica? Pluralismo cultural y religioso creciente. América Latina Hoy, 41, 17-34.

Handel, A. E., \& Ramagopalan, S. V. (2010). Is Lamarckian evolution relevant to medicine? BMC Medical Genetics, 11(1), 73. https://doi.org/10.1186/ 1471-2350-11-73

Huxley, T. H. (1901). Man's place in nature and others anthropological essay. MacMillan Company.

Jensen, M. S., \& Finley, F. N. (1995). Teaching evolution using historical arguments in a conceptual change strategy. Science Education, 79(2), 147-166. https://doi.org/10.1002/ sce.3730790203

Jungwirth, E. (1975). The problem of teleology in biology as a problem of biology-teacher education. Journal of Biological Education, 9(6), 243246. https://doi.org/10.1080/ 00219266.1975.9654037

Kampourakis, K. (2020). Students' "teleological misconceptions" in evolution education: why the underlying design stance, not teleology per se, is the problem. Evolution: Education and Outreach, 13(1), 1-12. https://doi.org/10. 1186/s12052-019-0116-z

Kampourakis, K., Palaiokrassa, E., Papadopoulou, M., Pavlidi, V., \& Argyropoulou, M. (2012). Children's intuitive teleology: Shifting the focus of evolution education research. Evolution: Education and Outreach, 5(2), 279-291. https://doi.org/10.1007/s12052012-0393-2

Kojonen, E. V. R. (2013). Tensions in intelligent design's critique of theistic evolutionism. Zygon ${ }^{\circledR}$, 48(2), 251-273. https://doi.org/10. $1111 /$ zygo. 12010

Kung, H. (2007). El principio de todas las cosas: Ciencia y religión. Trotta.

Lalueza-Fox, C. (2013). Palabras en el tiempo. Crítica.

Lamarck, J. B. (1914). Zoological philosophy. McMillan.

Leakey, R. E. (1997). A origem da espécie humana. "The origin of human species." Rocco. 
Lefevre, F., \& Lefevre, A. M. C. (2014). Discourse of the collective subject: social representations and communication interventions. Texto \& Contexto - Enfermagem, 23(2), 502-507. https://doi.org/ 10.1590/0104-070720140000000 14

Levesque, P., \& Guillaume, A. (2010). Teachers, evolution, and religion: No resolution in sight. Review of Religious Research, 51(4), 349-365. http://www.jstor.org/stable/20778 528

Losh, S. C., \& Nzekwe, B. (2011). Creatures in the classroom: Preservice teacher beliefs about fantastic beasts, magic, extraterrestrials, evolution and creationism. Science \& Education, 20(5-6), 473-489. https://doi.org/10.1007/s11191010-9268-5

Lovejoy, C. O. (1981). The origin of man. Science, 211(4480), 341-350. https://doi.org/10.1126/science.2 11.4480 .341

Mayr, E. (1974). Teleological and Teleonomic, a New Analysis. In R. S. Cohen \& M. W. Wartofsky (Eds.), Methodological and Historical Essays in the Natural and Social Sciences (Vol 14, pp. 91-117). Springer. https://doi.org/10.1007/ 978-94-010-2128-9_6

McGhee, G. R. (2016). Can evolution be directional without being teleological? Studies in History and Philosophy of Science Part C: Studies in History and Philosophy of Biological and Biomedical Sciences, 58, 93-99. https://doi.org/10.1016 /j.shpsc.2015.12.006

Medel, R., \& Veloso, A. (2009). Establecimiento y propagación del Darwinismo en Chile: Recepción y elaboración de las ideas. Gayana (Concepción), 73(1), 7-18. https://doi.org/10.4067/S071765382009000300002

Michaels, R. A., Hammerman, R. A., \& Silva, H. M. (2018). Emerging green synergy in the science/religion relationship: From conflict to potentially planet-saving cooperation. Environmental Claims Journal, 30(4), 314-336. https://doi.org/10.1080/10406026 .2018 .1504381

Miller, J. D. (2006). Science Communication: Public acceptance of evolution. Science, 313(5788), 765-766. https://doi.org/10.1126/science.1 126746

Nehm, R. H., \& Reilly, L. (2007). Biology majors' knowledge and misconceptions of natural selection. BioScience, 57(3), 263272. https://doi.org/10.1641/ B570311

Oleques, L. C., Bartholomei-Santos, M. L., \& Boer, e N. (2011). Evolução biológica: percepções de professores de biologia. Revista Electrónica de Enseñanza de Las Ciencias, 10(2), 243-263. http://reec.uvigo.es/volumenes/vo lumen10/ART2_VOL10_N2.pdf

Oliveira, G. da S., \& Bizzo, N. (2011). Aceitação da evolução biológica: atitudes de estudantes do ensino médio de duas regiões brasileiras. Revista Brasileira de Pesquisa Em Educação Em Ciências, 11(1), 57-79. https://periodicos.ufmg.br/index.p $\mathrm{hp} / \mathrm{rbpec} /$ article/view/4124

Oro, A. P. (2008). Religião, coesão social e sistema político na América Latina. iFHC/CIEPLAN.

Oser, F. K., Fetz, R. L., Reich, K. H., \& Valentin, P. (2003). Religious judgement and religious world view: Theoretical relationship and empirical findings. Archive for the Psychology of Religion, 25(1), 165179. https://doi.org/10.1163/ 157361203X00129

Paley, W. (2012). Natural Theology: Or, evidences of the existence and attributes of the deity, collected from the appearances of nature. Suzeteo Enterprises.

Pedersen, S., \& Halldén, O. (1994). Intuitive ideas and scientific explanations as parts of students' developing understanding of biology: The case of evolution. European Journal of Psychology of Education, 9(2), 127137. https://doi.org/10.1007/ BF03173548

Pennock, R. T. (2001). Intelligent design creationism and its critics: Philosophical, theological, and 
scientific perspectives (R. T. Pennock (ed.)). MIT Press.

Pérez, G., Gómez Galindo, A. A., \& González Galli, L. (2021). The regulation of epistemological obstacles in the learning of evolution. Enseñanza de Las Ciencias. Revista de Investigación y Experiencias Didácticas, 39(1), 27-44. https://doi.org/10.5565/rev/ensci encias. 2968

Pigliucci, M. (2009). Is intelligent design creationism? In K. Frazier (Ed.), Science Under Siege: Defending Science, Exposing Pseudoscience. Prometheus.

Prüfer, K., Munch, K., Hellmann, I., Akagi, K., Miller, J. R., Walenz, B., Koren, S., Sutton, G., Kodira, C., Winer, R., Knight, J. R., Mullikin, J. C., Meader, S. J., Ponting, C. P., Lunter, G., Higashino, S., Hobolth, A., Dutheil, J., Karakoç, E., ... Pääbo, S. (2012). The bonobo genome compared with the chimpanzee and human genomes. Nature, 486(7404), 527531. https://doi.org/10.1038/ nature 11128

Reda, S. (2016). Collaborative inquiry in ontario's kindergarten program. The International Journal of Holistic Early Learning and Development, 3(1), 72-77. https://ijheld.lake headu.ca/article/view/1502/834

Reiss, M. J. (2009). The relationship between evolutionary biology and religion. Evolution, 63(7), 19341941. https://doi.org/10.1111/ j.1558-5646.2009.00714.x

Ribeiro, M. G. L., Larentis, A. L., Caldas, L. A., Garcia, T. C., Terra, L. L., Herbst, M. H., \& Almeida, R. V. (2015). On the debate about teleology in biology: the notion of "teleological obstacle." História, Ciências, SaúdeManguinhos, 22(4), 1321-1333. https://doi.org/10.1590/S010459702015005000003

Ruiz, R. (1987). Positivismo y evolución: introducción del darwinismo en México. Universidad Nacional Autónoma de México.

Ruiz, Rosaura. (1987). Resistencia a Darwin en México: El caso de la biología. Omnia, 3(6), 51-57. http:// poseidon.posgrado.unam.mx/publi caciones/ant_omnia/06/08.pdf
Ruse, M. (2000). Teleology: yesterday, today, and tomorrow? Studies in History and Philosophy of Science Part C: Studies in History and Philosophy of Biological and Biomedical Sciences, 31(1), 213232. https://doi.org/10.1016/ S1369-8486(99)00046-1

Scott, E. C., \& Matzke, N. J. (2007). Biological design in science classrooms. Proceedings of the National Academy of Sciences, 104(Supplement 1), 8669-8676. https://doi.org/10.1073/pnas.070 1505104

Shanks, N. (2004). God, the devil, and Darwin: A critique of intelligent design theory. Oxford University Press.

Silva, H. M. (2015). Professores de Biologia e Ensino de Evolução: Uma perspectiva comparativa em países com contraste de relação entre Estado e Igreja na América Latina. (Doctoral Dissertation) [Universidade Federal de Minas Gerais, Belo Horizonte]. http://hdl.handle.net/1843/BUBDA3HFBJ

Silva, H. M. (2017). Intelligent design endangers education. Science, 357(6354), 880.1-880. https://doi. org/10.1126/science.aao3245

Silva, H. M., Carvalho, G. S., Silva, P. R., \& Gibram, D. E. (2016). A percepção sobre a hipótese do design inteligente no Brasil (Minas Gerais). Conexão Ciência (Online), 11(1), 6171. https://doi.org/10.24862/cco. v11i1.273

Silva, H. M., Oliveira, A. W., Belloso, G. V., Díaz, M. A., \& Carvalho, G. S. (2021). Biology teachers' conceptions of Humankind Origin across secular and religious countries: an international comparison. Evolution: Education and Outreach, 14(1), 2. https://doi.org/10.1186/ s12052-020-00141-9

Skrzypińska, K. (2014). The Threefold Nature of Spirituality (TNS) in a psychological cognitive framework. Archive for the Psychology of Religion, 36(3), 277-302. https://doi.org/10.1163/15736121 $-12341293$ 
Smith, C., \& Prokopy, J. (1999). Latin American religion in motion. Routledge.

Stover, S. K., \& Mabry, M. L. (2007). Influences of teleological and lamarckian thinking on student understanding of natural selection. Bioscene: The Journal of College Biology Teaching, 33, 11-18. https://files.eric.ed.gov/fulltext/EJ 849534.pdf

Taber, K. S. (2013). Conceptual frameworks, metaphysical commitments and worldviews: The challenge of reflecting the relationships between science and religion in science education. In $\mathrm{N}$. Mansour \& R. Wegerif (Eds.), Science Education for Diversity: Theory and Practice (pp. 151-177). Springer. https://doi.org/10.1007/978-94007-4563-6_8

Tamir, P. (1985). Causality and teleology in high school biology. Research in Science \& Technological Education, 3(1), 19-28. https://doi.org/10. 1080/0263514850030103

Tamir, P., \& Zohar, A. (1991). Anthropomorphism and teleology in reasoning about biological phenomena. Science Education, 75(1), 57-67. https://doi.org/10. 1002/sce.3730750106

Teixeira, P. M. M., \& Neto, e J. M. (2012). O estado da arte da pesquisa em ensino de Biologia no Brasil: um panorama baseado na análise de dissertações e teses. Revista Electrónica de Enseñanza de Las Ciencias, 11(2), 273-297. http://reec.uvigo.es/volumenes/vo lumen11/REEC_11_2_2_ex500.pdf

Woodford, P. (2016). Neo-Darwinists and Neo-Aristotelians: How to talk about natural purpose. History and Philosophy of the Life Sciences, 38(4), 1-23. https://doi.org/10. 1007/s40656-016-0123-0

Zohar, A., \& Ginossar, S. (1998). Lifting the taboo regarding teleology and anthropomorphism in biology education?Heretical suggestions. Science Education, 82(6), 679-697. https://doi.org/10.1002/(SICI)1098 -237X(199811)82:6<679::AIDSCE3>3.0.CO;2-E 